\title{
Gastric output of pancreatic secretory trypsin inhibitor is increased by misoprostol
}

\author{
R J Playford, J J Batten, T C Freeman, K Beardshall, D A Vesey, G C Fenn, J H Baron, J Calam
}

\begin{abstract}
Pancreatic secretory trypsin inhibitor (PSTI)

is a potent protease inhibitor that also has growth promoting activity. It has recently been identified in the foveolar cells of the stomach, which secrete mucus. We examined the effects of the prostaglandin $E_{1}$ analogue misoprostol on gastric PSTI output. Seven normal volunteers took part. An initial period of gastric aspiration was followed by four $\mathbf{4 0}$ minute periods of gastric perfusion at $5 \mathrm{ml} /$ minute of: $0.14 \mathrm{~mol} / \mathrm{l}$ saline, $0.17 \mathrm{mmol} / \mathrm{l}$ bicarbonate, bicarbonate with misoprostol $400 \mu \mathrm{g}$, and then bicarbonate again. All perfusates contained polyethylene glycol 4000 as a marker. Misoprostol increased median gastric secretion of PSTI from 11 to $33 \mu \mathrm{g} /$ hour $(\mathbf{p}<0.05)$, producing concentrations in gastric juice six times higher than those found in jejunal juice and about 1/30 of the values seen in pancreatic juice. Median mucus secretion increased to a lesser extent from 29 to $38 \mathrm{mg} / \mathrm{hour}$ during misoprostol. There was no change in intragastric concentrations of protein or of epidermal growth factor during infusion of misoprostol. Infusion of pentagastrin $(6 \mu \mathrm{g} / \mathrm{kg} /$ hour) had no effect on gastric secretion of mucus, PSTI, or protein. Human gastric mucus was degraded on incubation with trypsin in vitro and this was prevented by the addition of PSTI. These results suggest that gastric PSTI may protect the gastric mucus layer against refluxed pancreatic proteases. Increased output of PSTI during microprostol may contribute to the protective effect of this drug.
\end{abstract}

Pancreatic secretory trypsin inhibitor (PSTI) is a potent inhibitor of trypsin and chymotrypsin ${ }^{1}$ that has recently been found in the foveolar cells of the stomach as well as in the pancreas. ${ }^{23}$ The foveolar cells also secrete mucus, ${ }^{4}$ which helps to create the protective gastric mucus layer. ${ }^{5}$ We therefore speculated that PSTI may protect the gastric mucus layer from damage by pancreatic proteases that reflux into the stomach in normal people and, to a greater extent, in diseases including chronic gastric ulcer. ${ }^{6}$ Because the prostaglandin $E_{1}$ analogue misoprostol heals gastric ulcers ${ }^{7}$ and increases the concentration of mucus in gastric juice, ${ }^{8}$ we examined its effect on the gastric output of PSTI.

When considering the proposed protective effect of PSTI against pancreatic enzymes, it is important to note that both PSTI and trypsin are digested by pepsin, but only at a low $\mathrm{pH} .^{910}$ Pepsin, however, is inactive against trypsin and PSTI at pH values $>4^{9} 10$ - values that occur normally within the mucus layer ${ }^{5}$ and in the lumen when acid secretion is reduced by disease or drugs, ${ }^{112}$ buffered by food, or neutralised by refluxed duodenal juice. ${ }^{13}$ We therefore measured gastric PSTI both before and during intragastric neutralisation with bicarbonate. Epidermal growth factor was measured as a control protein of similar size to PSTI, present in gastric juice, but principally of salivary origin. ${ }^{1+}$

The effect of pentagastrin on gastric secretion of mucus was also investigated because pentagastrin has been reported to increase mucus secretion in the cat, ${ }^{15}$ but to decrease it in man. ${ }^{16}$

\section{Subjects and methods}

\section{ETHICS}

The study protocols were approved by the local ethics committee and all patients and volunteers gave informed consent.

EFFECT OF GASTRIC PERFUSION WITH SALINE, BICARBONATE, AND MISOPROSTOL

\section{Dose finding study}

In a preliminary experiment, a normal subject (a man, aged 42 years) took part in an extended study using methods described below. He underwent five $\mathbf{4 0}$ minute periods of perfusion with $0.17 \mathrm{mmol} / 1$ bicarbonate to which $0,0.2,1$, and $2 \mu \mathrm{g} / \mathrm{ml}$ misoprostol were added (giving doses of $0,40,200$, and $400 \mu \mathrm{g}$ over the relevant 40 minute periods).

\section{The main study}

Seven subjects took part in this study. After an overnight fast, a double lumen nasogastric tube was placed for continuous aspiration from the gastric antrum with infusion $20 \mathrm{~cm}$ proximally. Each study had five stages of 40 minutes each: aspiration only, perfusion with $0.14 \mathrm{~mol} / \mathrm{l}$ saline, perfusion with $0.17 \mathrm{~mol} / \mathrm{l}$ sodium bicarbonate, bicarbonate with $400 \mu \mathrm{g}$ misoprostol $(2 \mu \mathrm{g} / \mathrm{ml})$, and bicarbonate alone (Fig 1). Four subjects had a repeat study one week later with two stages of 40 minutes each - aspiration only followed by saline perfusion and then an 80 minute perfusion with $0 \cdot 17 \mathrm{~mol} / \mathrm{l}$ sodium bicarbonate (Fig 1 ). The perfusion rate was $5 \mathrm{ml} /$ minute and all perfusates contained $5 \mathrm{~g} / \mathrm{l}$ of polyethylene glycol 4000 and $0 \cdot 2 \%$ ethanol, which was required to dissolve the misoprostol. Aspirates were continuously collected on ice and were stored in 10 minute batches, mixed thoroughly, and samples titrated to the $\mathrm{pH}$ of the perfusate or, in the case of saline perfusion, to $\mathrm{pH} 7 \cdot 0$. Neutralised samples for radioimmunoassay were frozen and stored at $-20^{\circ} \mathrm{C}$. 


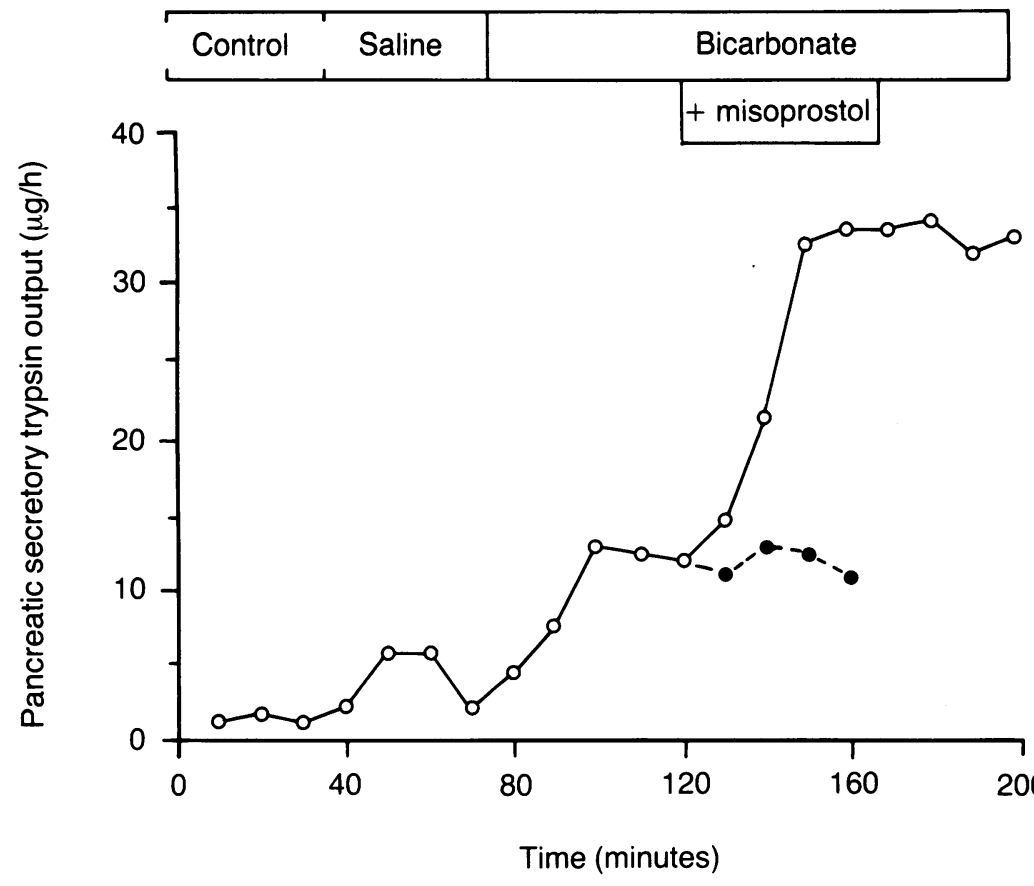

Figure 1: Gastric secretion of pancreatic secretory trypsin inhibitor (PSTI) in seven healthy volunteers (open circles). The study comprised five 40 minute stages: simple aspiration, then gastric perfusion with; $0 \cdot 14 \mathrm{~mol} / \mathrm{l}$ saline, $0.17 \mathrm{~mol} / \mathrm{l}$ sodium bicarbonate, bicarbonate with $400 \mu \mathrm{g}$ of misoprostol (MISO), then bicarbonate alone again. Intragastric perfusion with $400 \mu \mathrm{g}$ misoprostol caused a significant increase in output $(p<0.05)$ of PSTI which was maintained throughout the final bicarbonate period. The closed circles indicate results in four subjects in whom bicarbonate was continued without

misoprostol. minutes after the end of the study.

\section{EFFECT OF PENTAGASTRIN} forearm vein from $60-120$ minutes. analyser (Technical instruments Co) and Technitron method number SM-0179887. All samples were also analysed for trypsin using $\mathbf{N}$ Benzoyl-DL- Arginine p-Nitroanilide(BAPNA) as substrate. ${ }^{21}$ The lower limits of detection for bilirubin and trypsin were $2 \mu \mathrm{mol} / \mathrm{l}$ and $5 \mu \mathrm{g} / \mathrm{ml}$ respectively. Any samples containing detectable bilirubin or trypsin were discarded.

\section{EFFECT OF TRYPSIN ON HUMAN GASTRIC MUCUS} IN VITRO

Some $6 \mathrm{mg}$ of human gastric mucus glycoprotein, derived from $10 \mathrm{ml}$ of the gastric juice of a healthy volunteer were incubated with $100 \mu \mathrm{g}$ of bovine trypsin (Sigma Type III) in a total volume of $10 \mathrm{ml}$, in $0.1 \mathrm{~mol} / 1$ TRIS buffer $\mathrm{pH} 7.8$ with and without $26 \mu \mathrm{g}$ of human PSTI, an amount equimolar with the amount of trypsin added. After incubation for 24 hours at $37^{\circ} \mathrm{C}$, the mucus was analysed by gel filtration using a $16 \times 900$ $\mathrm{mm}$ Sephacryl S-500 column eluted with 0.05 $\mathrm{mmol} / 1 \mathrm{NaCl}$ at $21^{\circ} \mathrm{C}$. Eluates were analysed for mucus carbohydrate as described above.

To assess possible gastric damage resulting from the procedure or the drug, one volunteer was examined by fiberoptic endoscopy 30

The effect of pentagastrin was studied similarly in six subjects (five men and one woman, age range $21-45$ years). To neutralise stimulated acid, $0 \cdot 17 \mathrm{~mol} / \mathrm{l}$ sodium bicarbonate was perfused intragastrically at $10 \mathrm{ml} /$ minute for 180 minutes. Pentagastrin, $6 \mu \mathrm{g} / \mathrm{kg} / \mathrm{hour}$, was infused into a

\section{COLLECTION OF NORMAL FASTING DUODENAL JUICE}

Duodenal aspirates were obtained from four fasted healthy men via a weighted single lumen tube screened into the duodenojejunal junction. Samples were analysed for bilirubin, protein, trypsin, and PSTI.

\section{LABORATORY ANALYSES}

PSTI was measured using antiserum T4 as described previously, ${ }^{10}$ protein was analysed using a modified method of Lowery, ${ }^{17}$ and mucus carbohydrate analyses were by the phenol sulphuric method. ${ }^{8}$ Results were analysed using a galactose standard curve at an absorbance of $490 \mathrm{~nm}$. Epidermal growth factor was measured by the specific radioimmunoassay described by Savage. ${ }^{19}$ We examined the cross reactivity of transforming growth factor $\alpha$ in this assay. Polyethylene glyclol was measured in samples by a turbidometric method..$^{20}$ Gastric acid secretion was measured by back titrating aspirates to their original $\mathrm{pH}$, which was 8.3 for bicarbonate perfusion (or $\mathrm{pH} 7.0$ in the case of simple aspiration or saline perfusion) using a Metrohm automatic titrator (Switzerland). All aspirates were analysed for bilirubin using an RA-1000

\section{CALCULATIONS AND STATISTIC ANALYSIS}

For the study of the effects of misoprostol, all results were compared with those obtained during the first period of bicarbonate perfusion and analysed using the Wilcoxon rank paired test. Secretion rates were determined using polyethylene glycol dilution and polyethylene glycol recovery was used to correct for pyloric losses. The mean of the last two time points of each stage (final 20 minutes) for each individual subject was calculated as we considered that plateau values had been reached. The median (range) of the values from all the subjects are shown in the Table and the median of each individual 10 minute period for PSTI output is shown in Figure 1. Because acid, pepsin, epidermal growth factor, carbohydrate, and PSTI secretion were not normally distributed, results are expressed as median (range) and $\mathrm{p}<0.05$ was taken to be statistically significant.

\section{Results}

\section{EFFECTS OF MISOPROSTOL}

\section{Dose finding study}

In the single subject who received increasing doses of misoprostol, the measured outputs of PSTI were: $18,26,35$, and $31 \mu \mathrm{g} /$ hour after providing $0,40,200$, and $400 \mu \mathrm{g}$ over the 40 minute periods respectively. These results showed that the output of PSTI increased in a dose dependant manner with maximal stimulation being reached during the $200 \mu \mathrm{g}$ misoprostol per 40 minute dose $(1 \mu \mathrm{g} / \mathrm{ml})$. The $40 \mu \mathrm{g}$ misoprostol per 40 minute dose $(0.2 \mu \mathrm{g} / \mathrm{ml})$ increased PSTI output by $35 \%$ but did not affect the total volume of secretion, protein concentration, or acid output. Both the 200 and $400 \mu \mathrm{g}$ per 40 minute doses of misoprostol were associated with complete acid suppression. infusion of $0,0 \cdot 2,1$, and $2 \mu \mathrm{g} / \mathrm{ml}$ of misoprostol 
Effect of $400 \mu \mathrm{g}$ misoprostal on gastric luminal pancreatic secretory trypsin inhibitor (PSTI), mucus, protein, epidermal growth factor $(E G F)$, acid output, and volume of secretion in seven healthy volunteers, (values, median (range))

\begin{tabular}{lccc}
\hline & Perfusate & & \\
\cline { 2 - 4 } & $\begin{array}{l}\text { Initial } \\
\text { bicarbonate }\end{array}$ & $\begin{array}{l}\text { Misoprostol } \\
\text { bicarbonate }\end{array}$ & $\begin{array}{l}\text { Final } \\
\text { bicarbonate }\end{array}$ \\
\hline PSTI secretion $(\mu \mathrm{g} / \mathrm{hour})$ & $11(8-45)$ & $33(15-85)^{\star}$ & $32(23-85)^{\star}$ \\
PSTI concentration $(\mathrm{ng} / \mathrm{ml})$ & $127(75-222)$ & $386(173-599)^{\star}$ & $388(245-607)^{\star}$ \\
Mucus secretion $(\mathrm{mg} / \mathrm{hour})$ & $29(19-39)$ & $38(25-49)$ & $37(25-58)$ \\
Mucus concentration $(\mu \mathrm{g} / \mathrm{ml})$ & $245(222-399)$ & $372(257-661)$ & $432(250-664)^{\star}$ \\
Protein secretion $(\mathrm{mg} / \mathrm{ml})$ & $395(207-495)$ & $324(252-512)$ & $340(237-354)$ \\
Protein concentration $(\mathrm{mg} / \mathrm{ml})$ & $4 \cdot 0(2 \cdot 3-4 \cdot 8)$ & $2 \cdot 8(2 \cdot 0-5 \cdot 5)$ & $3 \cdot 1(2 \cdot 1-5 \cdot 0)$ \\
EGF secretion $(\mathrm{pmol} / \mathrm{hour})$ & $5 \cdot 4(1 \cdot 7-11 \cdot 5)$ & $6 \cdot 1(2 \cdot 3-11 \cdot 5)$ & $6 \cdot 4(1 \cdot 3-12 \cdot 3)$ \\
EGF concentration $(\mathrm{fmol} / \mathrm{ml})$ & $65(28-182)$ & $44(24-196)$ & $59(10-197)$ \\
Acid secretion $(\mathrm{meq} / \mathrm{hour})$ & $8 \cdot 8(0 \cdot 5-14 \cdot 5)$ & $-0 \cdot 6(-1 \cdot 5-12)^{\star}$ & $-0 \cdot 4(-4 \cdot 1-0)^{\star}$ \\
Volume of secretion $(\mathrm{ml} / \mathrm{hour})$ & $126(57-142)$ & $123(50-180)$ & $105(69-141)$ \\
\hline
\end{tabular}

The main study

Eighteen of the 140 samples were rejected because they contained bilirubin or trypsin; four from each of the aspiration, saline perfusion, and initial bicarbonate periods and two from each of the bicarbonate plus misoprostol and final bicarbonate periods.

Measured gastric output of PSTI was mean (range) $2(1-3) \mu \mathrm{g} / \mathrm{hour}$ during simple aspiration, 4 (3-5) $\mu \mathrm{g} / \mathrm{hour}$ during perfusion with saline, and rose to a plateau of $11(8-45) \mathrm{mg} /$ hour during the first bicarbonate period. Gastric secretion of PSTI remained at $11(7-21) \mu \mathrm{g} /$ hour (NS) when bicarbonate perfusion was continued without misoprostol for a further 40 minutes in four subjects. During perfusion with misoprostol, gastric secretion of PSTI rose to $33(15-85) \mu \mathrm{g} /$ hour $(\mathrm{p}<0.05)$. The maximal secretion rate was achieved after $200 \mu \mathrm{g}$ of misoprostol had been given. Calculated concentrations of PSTI in gastric juice also rose significantly from 127 (75$222) \mathrm{ng} / \mathrm{ml}$ to $386(173-599) \mathrm{ng} / \mathrm{ml}(\mathrm{p}<0.05)$ during misoprostol perfusion. The changes in PSTI secretion and concentration persisted throughout the second control period.

Gastric mucus secretion rose from 29 (19-39) $\mathrm{mg} /$ hour to 38 (25-49) $\mathrm{mg} /$ hour after misoprostol (NS). An increase in the concentrations of mucus in gastric juice became significant during the second control period: $432(250-664) \mu \mathrm{g} / \mathrm{ml}$ compared with $245(222-399) \mu \mathrm{g} / \mathrm{ml}(\mathrm{p}<0.05)$ before misoprostol.

Misoprostol also reduced acid secretion from $8.8(0.5-14.5) \mathrm{mEq} / \mathrm{hour}$ to $-0.6(-1.5-12)$ $\mathrm{mEq}$ /hour during misoprostol, and -0.4 $(-4 \cdot 1-0) \mathrm{mEq} /$ hour after misoprostol $(\mathrm{p}<0.05)$.

The $\mathrm{pH}$ of gastric aspirates was $1 \cdot 3-2 \cdot 8$ during basal aspiration, $2 \cdot 1-5 \cdot 0$ during perfusion with saline, 7.5-8.2 during the first bicarbonate period, 7.5-8.4 during misoprostol, and 8.3-8.7 during the final bicarbonate period.

There was no significant change in the total volume of secretion, measured by dilution of polyethylene glycol, or the rate of secretion of total protein or epidermal growth factor during or after misoprostol. Transforming growth factor $\alpha$ did not inhibit the binding of epidermal growth factor tracer to the antiserum in the epidermal growth factor radioimmunoassay. The ratio of bound: free epidermal growth factor tracer was 0.6 in the absence of added protein (final antibody concentration 1/80 000). Binding was $50 \%$ inhibited by $15 \mathrm{fmol}$ of epidermal growth factor/tube, but the ratio was $>0.58$ with
(A)

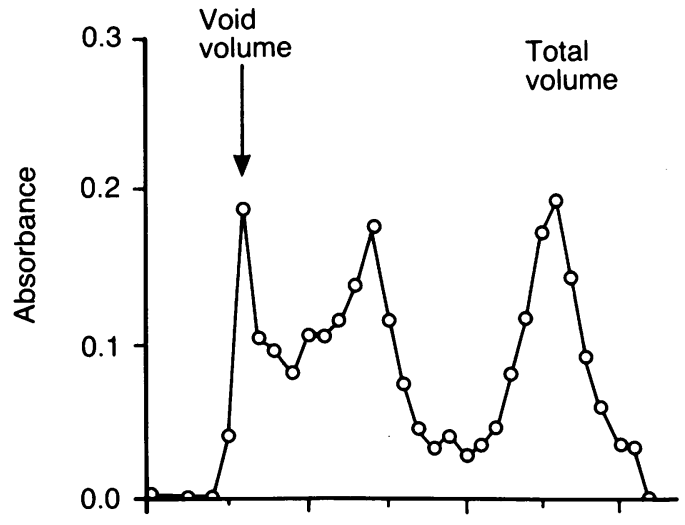

(B)

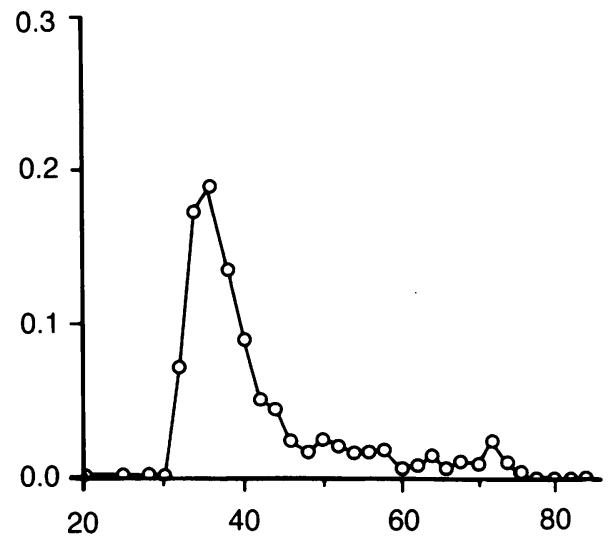

Fraction no

Figure 2: Damage to gastric mucus assessed by gel filtration. This separates molecules according to size, the largest eluting first. Normal mucus elutes as an early single peak indicated by an arrow in the void volume.

Total volume indicates column's total bed volume. $(A)$ After incubation with trypsin, the mucus elutes later indicating breakdown of its structure to smaller fragments. (B) The presence of pancreatic secretory trypsin inhibitor in the incubation medium prevented this destruction of mucus.

all concentrations of transforming growth factor $\alpha$ up to $150 \mathrm{pmol} /$ tube.

The subject who underwent endoscopy after the procedure had normal mucosa - both macroscopically and microscopically.

\section{EFFECT OF PENTAGASTRIN}

Pentagastrin had no apparent effect on gastric secretion of PSTI or mucus. Rates of PSTI output were 12 (7-19), 15 (7-26), and 10 (5-14) $\mu \mathrm{g} / \mathrm{hour}$, and rates of mucus output were 32 $(28-40), 31(25-36)$, and 29 (24-33) $\mathrm{mg} /$ hour before, during, and after pentagastrin respectively. The $\mathrm{pH}$ of the aspirates was never less than $7 \cdot 2$ during the study.

\section{EFFECT OF TRYPSIN ON HUMAN GASTRIC MUCUS IN} VITRO

After incubation of gastric mucus with trypsin, mucus carbohydrate eluted in three peaks: $20 \%$ eluted in the void volume (Vo, Kav=1), the remainder eluted later, principally in two peaks with $35 \%$ at an elution coefficient $(\mathrm{Kav})=0.3$ and 
$43 \%$ at $\mathrm{Kav}=0.89$, indicating breakdown of mucus glycoprotein to smaller forms (Fig $2 \mathrm{~A}$ ). In the presence of PSTI, however, $90 \%$ of mucus carbohydrate eluted at Vo, the characteristic position of native gastric mucus glycoprotein (Fig 2B).

\section{ANALYSIS OF DUODENAL JUICE}

Median (range) concentrations in duodenal aspirates were PSTI, $30(0-40) \mathrm{ng} / \mathrm{ml}$; trypsin, $195(150-290) \mu \mathrm{g} / \mathrm{ml}$; protein, 28 (18-57) $\mu \mathrm{g} /$ $\mathrm{ml}$; and bilirubin, $276(9-406) \mu \mathrm{mol} / \mathrm{l}$. The concentrations of PSTI were $0.1 \mathrm{mg}(0-0 \cdot 2)$ expressed per $100 \mathrm{mg}$ of protein in duodenal juice.

\section{Discussion}

These studies show the first time that a therapeutic dose of the synthetic prostaglandin $E_{1}$ derivative misoprostol increases gastric output of PSTI, and that PSTI can protect gastric mucus from damage by trypsin.

The protocol was based on knowledge of the nature of PSTI. Firstly, PSTI is destroyed by pepsin at $\mathrm{pH}<4,{ }^{10}$ so bicarbonate was used to keep the intragastric $\mathrm{pH}$ neutral during the last three test periods. The effect of this was tested by comparing measured PSTI output during administration of saline $v$ bicarbonate. Secondly gastric perfusion might 'wash' PSTI out of the mucus layer. Therefore the stomach was perfused at a constant rate during the last four test periods. Also at acid $\mathrm{pH}$, increased volume flow might decrease peptic hydrolysis by diminishing the time between its secretion and collection. To examine this we compared measured output between simple aspiration and saline perfusion. The results that we obtained are consistent with these ideas (Fig 1). There was a small transient rise in measured PSTI output during saline perfusion $v$ simple aspiration, a further significant rise when the perfusate was changed from saline to bicarbonate and a more substantial rise on the addition of misoprostol to bicarbonate. The latter increase did not occur when misoprostol was omitted during this time period in four subjects, indicating that the response was to misoprostol rather than to prolonged perfusion.

The prostaglandin $\mathrm{E}_{1}$ analogue (CL115,574, Lederle, NY, USA) which resembles misoprostol, significantly increased gastric mucus secretion in man and other animals. ${ }^{22}$ In our study, however, as in that of Wilson et al who also used misoprostol, ${ }^{8}$ there was a rise in mucus secretion that was not statistically significant. However in both studies the intragastric mucus concentration rose significantly, partly as a result of reduced secretion of water.

The rise in gastric PSTI output was specific because protein output did not change. The PSTI output rose more than mucus secretion, even though PSTI is derived from foveolar cells which secrete mucus. This may reflect selective stimulation of PSTI secretion or a difference between the recovery of PSTI and mucus.

It is not clear whether PSTI, with a molecular weight (MW) of 6000 , diffuses freely though the mucus layer or remains concentrated within it. A molecule of $\mathrm{MW} 1500$ diffused freely whereas one of MW 17000 did not. ${ }^{23}$ The mucus layer probably does retard the diffusion of trypsin which has a MW 23000 , so interactions between PSTI and trypsin probably occur at the luminal surface of the mucus layer.

PSTI probably protects the stomach from pancreatic proteases under conditions and in locations where the $\mathrm{pH}$ is high, so that both the PSTI and trypsin are active and not digested by pepsin. ${ }^{11}$ Gastric PSTI is most abundant in the antrum, ${ }^{3}$ which may be exposed to the highest concentrations of trypsin, while neutralised by refluxed duodenal contents. PSTI seems to be the only trypsin inhibitor in human gastric juice. Its concentration in gastric juice was about $130 \mathrm{ng} / \mathrm{ml}$ during gastric neutralisation and about $350 \mathrm{ng} / \mathrm{ml}$ after misoprostol compared with only about $30 \mathrm{ng} / \mathrm{ml}$ in normal duodenal juice. The low concentration in duodenal juice probably reflects the hydrolysis of gastric and pancreatic PSTI by the excess of pancreatic proteases present.

The gastric mucus layer is believed to protect the underlying epithelium by forming a diffusion barrier that allows secreted bicarbonate to keep the surface of the epithelial cells at a neutral $\mathrm{pH}$, as well as by protecting the mucosa from mechanical trauma by food. In patients with gastric ulcers, the mucus layer is abnormal, microscopically ${ }^{24}$ and biochemically, with an increased proportion of low molecular weight forms, ${ }^{25}$ suggesting proteolytic destruction. These patients tend to have reduced secretion of pepsin ${ }^{26}$ but increased duodenogastric reflux of trypsin, ${ }^{13}$ which we have shown produces changes in mucus very similar to those seen in gastric ulcer patients. ${ }^{25}$ PSTI greatly reduced this effect of trypsin, so stimulation of PSTI secretion by misoprostol may contribute to the therapeutic effect of this drug. However, misoprostol does stimulate other protective mechanisms and duodenal juice contains other substances such as bile salts that can damage the gastric mucus layer. Prokinetic drugs that diminish duodenogastric reflux ${ }^{27}$ may be beneficial in gastric ulcer disease.

The concentrations of epidermal growth factor measured in gastric juice in the present study are similar to those obtained by Konturek et al. ${ }^{14}$ Misoprostol did not affect intragastric epidermal growth factor, which is chiefly of salivary origin

In our study, as in that of Wilson et $a l^{8}$ misoprostol more or less abolished basal gastric acid secretion. Negative values may have been the result of misoprostol stimulated bicarbonate secretion $^{28}$ that may reduce the destruction of PSTI by acid pepsin in a non-neutralised stomach. The effects of misoprostol on our volunteers persisted for at least 40 minutes after the end of perfusion. Wilson et al showed that misoprostol's effects on acid and mucus secretion continue for at least 300 minutes after ingestion of $800 \mu \mathrm{g} .{ }^{8}$ The result of the dose finding study, taken with that of the main study, suggests that the dose of misoprostol required to increase PSTI output maximally is similar to that required to inhibit acid secretion. Our dose finding study in a single subject suggested, however, that 
$40 \mu \mathrm{g}$ of misoprostal can increase PSTI output without changing secretion.

Pentagastrin did not increase measured gastric PSTI output in the present study, although the same dose of pentagastrin did do so in our previous study which was based on simple aspiration of gastric juice. ${ }^{10}$ The difference probably reflects the different method used to collect gastric juice, as discussed above. During simple aspiration, pentagastrin stimulated volume flow may have 'washed' PSTI out of the mucus layer and reduced the duration of its exposure to acid pepsin. Gastric perfusion with bicarbonate may have reduced these effects in the present study. An increase in lumenal mucus during pentagastrin stimulation in the $\mathrm{cat}^{15}$ may also have been caused by 'washout'.

PSTI stimulates the growth of some normal and neoplastic cells, ${ }^{29}{ }^{30}$ at concentrations similar to those found in gastric juice. ${ }^{29}$ PSTI may therefore affect gastric epithelial growth and play a role in the stimulation of epithelial proliferation by misoprostol. ${ }^{31}$

Bronchial, nasal, and seminal mucus secretions all contain protease inhibitors, ${ }^{32}$ presumably to prevent proteolytic digestion of the mucus. Deficiency of $\alpha 1$ antitrypsin in the respiratory tract causes emphysema, ${ }^{33}$ probably through uninhibited tissue proteases. We propose that gastric PSTI may similarly protect the stomach. Further studies are required to examine its possible role in gastric disease.

The authors thank W Davis, $\mathrm{R}$ Davies, S K Li, Sister FrancisReme, and her staff for assistance during the study; the Medical Research Council for supporting RJP as a training fellow; and the Wellcome trust for support for TCF as a research assistant.

1 Kazal LA, Spicer DS, Brahinsky RA. Isolation of a crystalline trypsin-inhibitor-anticoagulant protein from the pancreas. F Am Chem Soc 1948; 70: 304-40.

2 Fukayama M, Hayashi Y, Koike M, Ogawa, M, Kosaki G. Immunohistochemical localisation of pancreatic secretory trypsin inhibitor in fetal and adult pancreatic and extrapancreatic tissue. $\mathcal{F}$ Histochem Cytochem 1986; 34: 227-35.

3 Freeman T, Playford R, Beardshall K, Francis-Reme M, Levi S. Calam J. Pancreatic secretory trypsin inhibitor in human gastrointestinal epithelia and gastric juice. Clin Sci 1989; 76 (suppl 20): 9 .

4 Itu S. Functional gastric morphology. In: Physiology of the gastrointestinal tract. Vol 1. L Johnson, ed. New York: gastrointestinal tract.

5 Rees WDW, Turnberg LA. Mechanism of gastric mucosal protection: a role for the mucus bicarbonate barrier. Clin Sci 1982; 62: 343-8.

6 Flint FJ, Grech P. Pyloric regurgitation and gastric ulcer. Gut 1970; 11: 735-7.

7 Rachmilewitz D, Chapman JW. Nicholson PA. A multicentre international controlled comparison of two dosage regimens of misoprostol with cimetidine in treatment of gastric ulcer in out patients. Dig Dis Sci 1985; 30 (suppl): 171-7.

8 Wilson D, Quadros E, Rajapaksa T, Adams A, Noar $M$. Effects of misoprostol on gastric acid and mucus secretion in man. Dig Dis Sci 1986; 31: 126-9.
9 Heizer WD, Cleaveland CR, Iber FL. Gastric inactivation of pancreatic supplements. Bullfohns Hopkins Hosp 1965; 116: 261-70.

10 Freeman TC, Playford RJ, Quinn C, et al. Pancreatic secretory trypsin inhibitor in gastrointestinal mucosa and gastric juice. Gut 1990; 31: 1318-23.

11 Lanzon-Miller S, Pounder R, Hamilton M, et al. Twenty-four hour intragastric acidity and plasma gastrin concentration in healthy subjects and patients with duodenal or gastric ulcer, or pernicious anaemia. Aliment Pharmacol Therap 1987; 1: 225-37.

12 Walt RP, Gomes M, Wood EC, Logan LH, Pounder RE. Effect of daily omeprazole on 24 hour intragastric acidity. BMF 1983; 287: 12-3.

13 Rhodes J, Barnado DE, Sidney MB, et al. Increased refux of bile into the stomach in patients with gastric ulcer. Gastroenterology 1969; 57: 241-52.

14 Konturek J, Bielanski W, Konturek S, Bogdal J, Oleksy J. Distribution and release of epidermal growth factor in man. Gut 1989; 30: 1194-200.

15 Vagne M, Perret G. Regulation of gastric mucus secretion. Scand $\mathcal{F}$ Gastroenterol 1976; 42: 63-74.

16 Clamp J, Brown P. Studies upon the secretion of gastric mucus from normal subjects. In: Chantler EN, Elder JB, Elstein M. Advances in experimental medicine and biology. Mucus in health and disease II. Vol 144. New York: Plenum Press, 1982: 135-6.

17 Schacterle G, Pollack R. A simplified method for the quantitative assay of small amounts of protein in biological material. Ann Biochem 1973; 51: 654-55.

18 Dubois M, Gilles KA, Hamilton JK, Rebers PA, Smith F. Calorimetric method for the determination of sugars and related substances. Anal Chem 1956; 28: 350-6.

19 Savage AP, Chatterjee VK, Gregory H, Bloom SR. Epidermal growth factor in blood. Regul Pept 1986; 16: 199-206.

20 Hyden S. A turbidometric method for the determination of higher polyethylene glycols in biological materials. Kungl Lantbrukshogskolans Annaler 1955; 22: 139-45.

21 Smith C, Van Megan W, Twaalfhoven L, Hitchcock C. The determination of trypsin inhibitor levels in foodstuffs. $\mathcal{F} \mathrm{Sci}$ determination of trypsin inhibit
Food Agric 1980; 31:341-50.

22 Wilson D. A new PGE1 analogue (CL115,574) III. Effects on gastric acid and mucus secretion in man. Prostaglandins $1984 ; 28: 5-11$.

23 Allen $A$. The structure and function of gastrointestinal mucus. In: Basic mechanisms of gastrointestinal mucosal cell injury and protection. Harmon JW ed. Baltimore: Williams and Wilkins, 1981: 351-7.

24 Allen A, Hutton DA, Leonard AJ, Pearson JP, Sellers LA. The role of mucus in the protection of the gastoduodenal mucosa. Scand F Gastroenterol 1986; suppl 125: 21: 71-8.

25 Younan F, Pearson J, Allen A, Venables C. Changes in the structure of the mucus gel on the mucosal surface of the stomach in association with peptic ulcer disease. Gastrostomach in association with

26 Johnson HD, Love AHG, Rogers NC, Wyatt AP. Gastric ulcers, blood groups and acid secretion. Gut 1964; 5: 402

27 Rezende-Filo J, Di-Lorenzo C, Dooley CP, Alenzuela JE. Cisapride stimulates antral motility and decreases biliary reflux in patients with severe dyspepsia. Dig Dis Sci 1989; 34: 1057-62.

28 Isenberg JI, Hogan DL, Koss MA, Selling JA. Human duodenal mucosal bicarbonate secretion. Gastroenterology 1986; 91 : 370-8.

29 Ogawa M, Tsushima T, OhbaY, et al. Stimulation of DNA synthesis in human fibroblasts by human pancreatic secretory synthesis in human fibroblasts by human pancreatic secretory 1985; 50: 155-8.

30 Freeman TC, Curry BJ, Calam J, Woodburn JR. Pancreatic secretory trypsin inhibitor (PSTI) stimulates growth of AR4 $-2 \mathrm{~J}$ rat pancreatic carcinoma cells. Gastroenterology 1990; 99: $1414-20$.

31 Goodland RA, Magwick AJ, Allen J, Wright NA. Prostaglandins and the gastric epithelium: trophic effects of misoprostol on gastric epithelial cell proliferation in the dog. Gut 1988; 29: A738.

32 Fritz $\mathrm{H}$. Human mucus proteinase inhibitor (human MPI) Biol Chem Hoppe Seyler 1988; 369 (suppl 369): 79-82.

33 Wetherall DJ, Ledingham JGG, Warrell DA, eds. Publications, Oxford Textbook of Medicine. Vol 2. 13th ed. Oxford: Oxford Medical 1983; 15.66. 